\title{
Oral health knowledge of parents of children and adolescents with congenital heart disease
}

\author{
Conhecimento dos pais de crianças e adolescentes \\ com cardiopatia congênita sobre saúde oral
}

\author{
Caroline Louise Sampaio PINHEIRO' ${ }^{1}$ iD 0000-0002-3432-9176 \\ Ana Cláudia Lima de Oliveira MEIRA² iD 0000-0002-3493-224X \\ Aline Silva dos SANTOS ${ }^{3}$ iD 0000-0001-9491-0053 \\ Delson Araujo SILVA4 iD 0000-0001-5060-1371
}

\section{ABSTRACT}

Objective: To assess the knowledge on oral hygiene, infective endocarditis, and antibiotic prophylaxis of parents of children and adolescents with heart diseases assisted at the Hospital Ana Nery (reference hospital), Salvador, Bahia, Brazil. Methods: Cross-sectional study with 43 guardians of children and adolescents aged 2 through 16 years, performed with the application of a questionnaire. Results: In the sample of parents studied, $64 \%$ had completed high school and $47 \%$ had a monthly family income of up to one minimum wage. The majority (81\%) reported knowing that oral infections may lead to heart complications, $42 \%$ knew that oral bacteria may migrate to the heart, and $51 \%$ knew the term infective endocarditis. When questioned about antibiotic prophylaxis, $93 \%$ had no knowledge about it and $88 \%$ did not know the reasons for using antibiotics before dental treatment. Conclusion: Parental knowledge was limited and fragmented. Further attention is required when transmitting information to parents, focusing on prevention strategies in order to guarantee the integral health of these children and adolescents.

Indexing terms: Endocarditis. Oral Health. Congenital heart diseases.

\section{RESUMO}

Objetivo: Avaliar o conhecimento sobre higiene bucal, endocardite infecciosa, e profilaxia antibiótica dos pais de crianças e adolescentes com cardiopatia congênita assistidas no Hospital Ana Nery, Salvador, Bahia. Métodos: Estudo transversal envolvendo 43 responsáveis de crianças e adolescentes de 2 a 16 anos, realizado através da aplicação de questionário. Resultados: Na amostra de pais estudada, 64\% possuíam ensino médio completo e $47 \%$ tinham como renda familiar até um salário mínimo. A maioria (81\%) afirmou ter conhecimento que infecções bucais podem levar a complicações cardiacas, 42\% sabiam que bactérias da boca podem

$\checkmark \nabla \nabla v$

1 Universidade Federal da Bahia, Faculdade de Odontologia, Pós Graduação em Odontologia e Saúde. Av. Araújo Pinho, Canela, 40110-040, Salvador, BA, Brasil. Correspondência para / Correspondence to: CLS PINHEIRO. E-mail: <carolinelouisesp@yahoo.com.br>.

2 Universidade de UNIARARAS, Fundação Hermínio Ometto. Araras, SP, Brasil.

${ }^{3}$ Faculdade São Leopoldo Mandic, Instituto de Pesquisas São Leopoldo Mandic, Endodontia. Campinas, SP, Brasil.

${ }^{4}$ Universidade Federal de São Paulo, Mestrado Morfologia/Genética. São Paulo, SP, Brasil.

$\checkmark \nabla \nabla$

How to cite this article

Pinheiro CLS, Meira ACLO, Santos AS, Silva D. Oral health knowledge of parents of children and adolescents with congenital heart disease. RGO, Rev Gaúch Odontol. 2019;67:e20190046. http://dx.doi.org/10.1590/1981-86372019000463625 
ir para o coração e 51 \% conheciam o termo endocardite infecciosa. Quando questionados o que é profilaxia antibiótica, 93\% não sabiam o que é e $88 \%$ desconheciam os motivos que levavam a necessidade do uso de antibióticos anteriormente a procedimentos odontológicos. Conclusão: O conhecimento dos pais mostrou-se limitado e fragmentado. É necessária maior atenção na transmissão da informação aos mesmos, focando em estratégias de prevenção a fim de garantir a saúde integral destas crianças e adolescentes.

Termos de indexação: Endocardite. Saúde bucal. Cardiopatias congênitas.

\section{INTRODUCTION}

Congenital heart disease (CHD) is a congenital malformation of the heart or the large intrathoracic vessels, with either actual or potential functional significance. Interatrial communication, interventricular communication, persistence of the arterial duct, and others are among the main defects [1]. In Brazil, in 2010, when applying a prevalence rate of CHD of 9:1 000 births, 25,757 new cases were estimated within the $2,861,868$ births of that year [2].

Several CHD patients are susceptible to infective endocarditis (IE), which may be triggered by the bacteremia from dental procedures or from daily toothbrushing and mastication habits [3]. The pathogens originate from the bacterial biofilm and are the leading etiological factors of infectious oral diseases such as periodontal disease and dental caries, which are the main illnesses of the oral cavity [4].

The IE presents high morbimortality rates and results from the interaction between the pathogenic agent present in the blood stream with molecular matrices and platelets attached to sites of endocardial cell damages. Several of the clinical manifestations of IE patients develop through a host immune response to the infecting microorganism [3]. The infection may be caused by bacteria, fungi, rickettsia, and chlamydia. Endocardial damage may occur by inflammation (rheumatic disease) or trauma determined by turbulent blood flow (arteriovenous shunt) [5].

Children with CHD may require specific care, considering they present physiological characteristics typical of cardiac malfunction. The oral health of CHD patients requires major attention, with the need for regular dental follow-up. Some studies have shown worse oral conditions for children with CHD when compared to healthy ones, associated with a knowledge deficit from the guardians regarding oral hygiene and the relationship of oral sites of infection with IE, as well as their health risks [6-8].
Therefore, this study aims to assess the knowledge of parents of children and adolescents with CHD assisted at the Hospital Ana Nery on oral hygiene, infective endocarditis, and antibiotic prophylaxis.

\section{METHODS}

It is a descriptive and cross-sectional study developed at the pediatric ward and ICU and the dental outpatient clinic of the Hospital Ana Nery, which is a cardiology service reference of the Brazilian public health system, located in the city of Salvador, Bahia, Brazil.

One single researcher collected the data after project approval by the Research Ethics Committee of the Hospital Ana Nery, with opinion number CAAE 64093717.9.0000.0045, according to Resolution no. 466 of December 12, 2012.

The convenience sample was obtained from May to December 2017 and included parents (older than 18 years) of pediatric and adolescent congenital heart disease (CHD) patients aged 2 through 16 years, hospitalized in either the pediatric ward or ICU, and patients who sought outpatient care at the hospital's dental clinic. After the researcher explained the objectives of the study when approaching the parents, those who accepted to participate signed the Informed Consent Form.

The information were collected through the application of a questionnaire with questions related to the social condition of the family, care practices learned from the multi-professional team after diagnosing the heart disease, practice and knowledge on oral hygiene, and diet habits. The researcher created the questionnaire along with the dental team of the hospital, considering the daily demands when assisting such patient profile.

The questions were read and explained so the participants would easily understand. This step was performed away from other people to ensure the comfort and privacy of the participants. 
The data were digitized in the Microsoft Excel ${ }^{\mathrm{TM}}$ 2007 software, assessed for absolute and relative frequencies of events, and subjected to descriptive analysis.

\section{RESULTS}

A total of 43 guardians accepted to answer the questionnaire, including 7 fathers and 36 mothers with average age of 36.14 years (ranging from 22 to 68 years old). From these, $84 \%$ were born upstate and the majority of $60 \%$ of them lived in the urban area. As for level of education, $28 \%$ had not completed high school and $26 \%$ had completed high school. More than half of the sample performed labor activities (53\%) and the occupations most mentioned were housekeeper (16\%) and farm worker $(16 \%)$. Most of them had a monthly family income of up to one minimum wage (47\%) (table 1).

The average age of the children was 7.3 years (ranging from 2 to 14 years old) and the great majority of school-aged children (77\%) were enrolled in educational institutions. Most of them was diagnosed with congenital heart disease (CHD) between 2 and 5 years old (42\%),

Table 1. Socioeconomic/demographic profile of the parents of children and adolescents with congenital heart disease assisted at the Hospital Ana Nery, Salvador (BA), 2017.

\begin{tabular}{|c|c|c|}
\hline Variable & $\mathrm{n}$ & $\%$ \\
\hline \multicolumn{3}{|l|}{ Sex } \\
\hline Male & 7 & $16 \%$ \\
\hline Female & 36 & $84 \%$ \\
\hline \multicolumn{3}{|l|}{ Origin } \\
\hline Urban & 26 & $60 \%$ \\
\hline Rural & 17 & $40 \%$ \\
\hline Upstate & 36 & $84 \%$ \\
\hline City of Salvador & 7 & $16 \%$ \\
\hline \multicolumn{3}{|l|}{ Level of education } \\
\hline Illiterate & 2 & $5 \%$ \\
\hline Incomplete Elementary School & 12 & $28 \%$ \\
\hline Complete Elementary School & 5 & $12 \%$ \\
\hline Incomplete High School & 08 & $19 \%$ \\
\hline Complete High School & 11 & $26 \%$ \\
\hline Incomplete Higher Education & 3 & $7 \%$ \\
\hline Complete Higher Education & 2 & $5 \%$ \\
\hline \multicolumn{3}{|c|}{ Are you a recipient of Bolsa Familia (Brazilian social program)? } \\
\hline Yes & 16 & $37 \%$ \\
\hline No & 27 & $63 \%$ \\
\hline \multicolumn{3}{|l|}{ Labor activity } \\
\hline Performs labor activity & 20 & $47 \%$ \\
\hline Does not perform labor activity & 23 & $53 \%$ \\
\hline \multicolumn{3}{|l|}{ Occupation } \\
\hline Housekeeper & 7 & $16 \%$ \\
\hline Farm worker & 7 & $16 \%$ \\
\hline Housewife & 4 & $9 \%$ \\
\hline Teacher & 4 & $9 \%$ \\
\hline Other activities & 21 & $50 \%$ \\
\hline
\end{tabular}


among which $65 \%$ had been subjected to previous surgery and $65 \%$ were off medications. Present in $14 \%$ of patients, interatrial communication was the most prevalent heart disease, but $30 \%$ of parents could not inform the correct congenital disease of their children. An expressive part of the sample (74\%) affirmed having received the first care instructions from physicians and 19\% reported having never received any.

According to the parents, $86 \%$ of children had already been to the dentist and $70 \%$ had a dental visit at least six months prior to the day of questionnaire application. The majority had access to a dentist through the Brazilian public health system (67\%) and in 53\% of cases, the reason for the appointment was medical recommendation (table 2). Among the last procedures performed in the children who had visited the dentist, $65 \%$ involved restorations and/or extractions due to caries.

When asked whether they considered the oral hygiene of their children satisfactory, $72 \%$ of parents said yes (table 3). Some of them associated the justification for the positive response with toothbrushing frequency, as seen in the following responses:

GUARDIAN 21 - "I think it is good because I do it at home (referring to toothbrushing) and you (hospital dental team) do it here".

GUARDIAN 22 - "I make her brush 3 to 4 times a day".

As for oral hygiene instructions for child care, 70\% of parents reported having received instructions and most of them were instructed at the dental office (58\%) (Table 03). Thus, $65 \%$ of parents said their children brushed their teeth 3 times a day, $67 \%$ said the children did not use dental floss daily, and $86 \%$ said the children had no gingival bleeding (table 3).

Overall, the guardians claimed to monitor the oral hygiene practice of their children (91\%). All children had their own toothbrush and there was no family sharing. According to parents, most children had experienced

Table 2. Information on the access to dental treatment of children and adolescents with congenital heart disease assisted at the Hospital Ana Nery, Salvador (BA), 2017.

\begin{tabular}{|c|c|c|}
\hline Variable & $n$ & $\%$ \\
\hline \multicolumn{3}{|c|}{ Has your child been to the dentist? } \\
\hline Yes & 37 & $86 \%$ \\
\hline No & 6 & $14 \%$ \\
\hline \multicolumn{3}{|c|}{ When was your child's last dental visit? } \\
\hline Up to 06 months & 30 & $70 \%$ \\
\hline 06 months to 01 year & 5 & $12 \%$ \\
\hline From 01 to 02 years & 2 & $5 \%$ \\
\hline \multicolumn{3}{|c|}{ How did you access the dentist? } \\
\hline Private service & 7 & $16 \%$ \\
\hline Health plan & 1 & $2 \%$ \\
\hline Public health system & 29 & $67 \%$ \\
\hline \multicolumn{3}{|c|}{ Who instructed the family to seek dental care? } \\
\hline Physician & 23 & $53 \%$ \\
\hline Other health professional & 1 & $2 \%$ \\
\hline Relative & 1 & $2 \%$ \\
\hline Myself & 12 & $28 \%$ \\
\hline
\end{tabular}


Table 3. Guardian perception on oral hygiene and gingival bleeding of children and adolescents with congenital heart disease assisted at the Hospital Ana Nery, Salvador (BA), 2017.

\begin{tabular}{|c|c|c|}
\hline Variable & $\mathrm{n}$ & $\%$ \\
\hline Yes & 31 & $72 \%$ \\
\hline No & 12 & $28 \%$ \\
\hline \multicolumn{3}{|c|}{ Have you received oral hygiene instructions? } \\
\hline I don't know & 2 & $5 \%$ \\
\hline \multicolumn{3}{|c|}{ Where did you receive oral hygiene instructions? } \\
\hline Dental office & 25 & $58 \%$ \\
\hline Did not receive & 13 & $30 \%$ \\
\hline \multicolumn{3}{|c|}{ How many times a day does your child perform oral hygiene? } \\
\hline $1 \mathrm{x}$ & 2 & $5 \%$ \\
\hline $2 x$ & 13 & $30 \%$ \\
\hline $3 x$ & 28 & $65 \%$ \\
\hline Unknown & 1 & $2 \%$ \\
\hline \multicolumn{3}{|c|}{ Does your child use dental floss? } \\
\hline Yes & 14 & $33 \%$ \\
\hline
\end{tabular}

toothache (53\%). When asked whether the children consumed a lot of sweets, $40 \%$ of parents said yes and $95 \%$ reported understanding that sweets may harm oral health (table 4).

A total of $42 \%$ of parents knew that oral bacteria might migrate to the heart. Regarding IE, $51 \%$ of parents knew the meaning of it. Most parents (81\%) reported knowing about the relationship between oral and heart diseases (table 5). When asked on how they thought such relationship occurs, some parents justified as follows:

GUARDIAN 6 - "The tooth harms the heart. She took so many medications".

GUARDIAN 8 - "The doctor said so, because of the microbes".
GUARDIAN 12 - "Because the same bacteria in the tooth may harm the heart".

Almost the entire sample (93\%) did not know the meaning of the term "antibiotic prophylaxis". After learning the meaning of the term in a more familiar language from the questionnaire applicator, $88 \%$ of parents still could not understand the reason for the need of prophylaxis. On the other hand, 95\% deemed important to perform dental treatment before heart surgery (table 5).

More than half of the guardians (63\%) reported having been informed about the oral hygiene care required for CHD patients immediately after diagnosis. Mainly physicians (85\%) and dentists (07\%) transmitted such instructions (table 6). 
Table 4. Guardian information on oral hygiene practice, sugar intake, and the presence of toothache in children and adolescents with congenital heart disease assisted at the Hospital Ana Nery, Salvador (BA), 2017.

\begin{tabular}{|c|c|c|}
\hline \multicolumn{3}{|c|}{ Do you monitor your child's toothbrushing? } \\
\hline No & 4 & $9 \%$ \\
\hline Yes & 39 & $91 \%$ \\
\hline No & 43 & $100 \%$ \\
\hline \multicolumn{3}{|c|}{ Has your child experienced toothache? } \\
\hline No & 20 & $47 \%$ \\
\hline Yes & 23 & $53 \%$ \\
\hline Yes & 17 & $40 \%$ \\
\hline No & 2 & $5 \%$ \\
\hline Yes & 41 & $95 \%$ \\
\hline
\end{tabular}

\section{DISCUSSION}

A perception on multidisciplinary care from the guardians of children and adolescents with congenital heart disease (CHD) is essential and facilitates the maintenance of the quality of life of such patients. However, their understanding on oral health and the repercussions for developing a potential infective endocarditis (IE) is inadequate and full of gaps $[9,10]$.

In this study, most parents reported knowing that oral infections may lead to cardiac complications, but only slightly more than half of them knew the term infective endocarditis, while less than half knew that oral bacteria might result in bacteremia and cause cardiac complications. The contradiction of such knowledge may be seen not only in the quantitative results aforementioned, but also in the speech of some guardians, whose justification on the relationship of oral infections with cardiac complications differed from the reality.

The lack of knowledge on IE among cardiac patients is concerning, as shown in the study by Amaral et al. [11], which among a sample of 75 adult patients hospitalized in pre-cardiac surgery found that $89.3 \%$ ignored the risks of IE. Among such patients, 58.6\% required dental treatment.
Corroborating previous studies $[7,12,13]$, most of the sample studied in the present one did not know the term "antibiotic prophylaxis" and did not understand the reason antibiotics are used before some dental procedures. These results are not compatible with the diagnosis time of 2 to 5 years prevailing in the sample and with the number of children and adolescents that had been subjected to previous surgeries, considering that preoperative dental care is of utmost importance for removing potential sources of oral infections that may cause bacteremia. It is evident the lack of interaction of the multidisciplinary teams and the absence of satisfactory knowledge transmission to these guardians.

The relationship between information deficit and low level of education $[8,10,12]$ was also observed in the present study, considering that most of the sample had not completed high school (although statistical tests were not performed). The present study differs from the studies by Cetta et al. [13] and Cheuk et al. [10], which found gaps in parental understanding even with most of the sample having completed high school. Thus, the way such knowledge is acquired is questionable, which evidences a superficiality of the information transmitted.

Most parents showed satisfactory knowledge on the oral health care of their children, when considering 
Table 5. Perception of the guardians of children and adolescents with congenital heart disease assisted at the Hospital Ana Nery, Salvador (BA), 2017 on the relationship between oral and systemic health and antibiotic prophylaxis.

\begin{tabular}{|c|c|c|}
\hline Variable & $\mathrm{n}$ & $\%$ \\
\hline \multicolumn{3}{|c|}{ Do you know that oral bacteria may go to the heart? } \\
\hline No & 25 & $58 \%$ \\
\hline \multicolumn{3}{|c|}{ Do you know what infective endocarditis means? } \\
\hline No & 20 & $47 \%$ \\
\hline I don't know & 1 & $2 \%$ \\
\hline \multicolumn{3}{|c|}{ In your opinion, is there a relationship between oral and heart diseases? } \\
\hline I don't know & 1 & $2 \%$ \\
\hline \multicolumn{3}{|c|}{ Do you know what antibiotic prophylaxis means? } \\
\hline Yes & 3 & $7 \%$ \\
\hline No & 40 & $93 \%$ \\
\hline \multicolumn{3}{|c|}{ Do you know why these patients need antibiotic prophylaxis? } \\
\hline Yes & 5 & $12 \%$ \\
\hline No & 38 & $88 \%$ \\
\hline \multicolumn{3}{|c|}{ Do you think dental treatment is important before surgery? } \\
\hline
\end{tabular}

Table 6. Perception of the guardians of children and adolescents with congenital heart disease assisted at the Hospital Ana Nery, Salvador (BA), 2017 on the importance of dental treatment.

\begin{tabular}{lcc}
\hline Variable & $\mathrm{n}$ & \\
\hline After diagnosis, did someone instruct you on oral care and dental visits? & 27 & $63 \%$ \\
Yes & 16 & $37 \%$ \\
No & & \\
What professional informed you about oral care and dental visits? & 2 & $7 \%$ \\
Dentist & 23 & $85 \%$ \\
Physician & 1 & $2 \%$ \\
Other professional & & \\
\hline
\end{tabular}

that most of them claimed having received oral hygiene instructions, monitoring their children's toothbrushing, and that a great number of children had visited the dentist 6 months earlier and brushed their teeth 3 times a day. The truth of such information is debatable when comparing with the responses obtained from other variables hereby discussed.

Considering numerous discrepancies regarding the knowledge on IE and oral health, the present study may not leave out the fact that a dental professional 
related to assistance interviewed the parents, which may have led them to give inconsistent responses to please the professional or out of embarrassment.

This suspicion is plausible, considering there was a high rate of children and adolescents who had experienced toothache and a significant number of them had been subjected to restorations or extractions due to caries. This is observed in other populations such as India, where $78 \%$ of the parents said they only take their children to the dentist in case of pain [8], which leads to the perception that curative dentistry still prevails over preventive dentistry in this group and that the knowledge acquired is not practiced in daily habits.

Another explanation for the high rates of oral disease observed may be justified by the excessive benevolence of parents on the heart disease of their children, which makes them offer sweets as a reward [14]. In the present study, almost all the parents interviewed knew the harm sweets may cause to oral health, but part of them reported the children consume sweets regularly. The emotional and functional overload than involves the process of child care or the crying of children when performing hygiene causes the parents to potentially neglect oral health care [14-16].

Moreover, one risk factor for developing oral diseases is the constant use of pediatric drugs with sugar for palate appeal, which parents not always see as a potential villain $[17,18]$.

Parents treat the use of dental floss with neglect, considering that more than half of children and adolescents did not use it. A study with 307 guardians of children aged 2 through 8 years concluded that 229 did not floss. Among the main reasons reported to explain the negligence for the auxiliary method of oral hygiene, 89 mothers affirmed that it occurred because the children do not let them, 110 reported lack of habit, 86 found the product expensive, and 43 said it takes too long [19]. Such issues listed above are compatible with the work overload of the parents from the sample of the present study and their income.

A good protocol for assisting cardiac patients requires planning for future dental clinical procedures, considering the social determinants and the living conditions of caregivers and patients. Hence, satisfactory anamnesis and definition of risk factors are essential for treatment selection and for determining the need for antibiotic prophylaxis [20]. Bonding is also required, as well as the sensitivity to listen to patients and their needs, seeking a treatment plan that includes the needs and expectations of both patients and guardians [21].

There are many flaws in the learning process of these guardians, for both the knowledge on oral hygiene habits and the interrelation between oral diseases and their complications in $\mathrm{CHD}, \mathrm{IE}$, and the care required to prevent them, such as the use of antibiotic prophylaxis. It was detected that communication in the service of the hospital studied is still weak for the professional-patient relationship and between the medical-dental teams, which is also challenged by the social determinants of the population. However, such reality is seen in the world literature.

Dental care in the Brazilian public health system is still recent. The National Oral Health Program - Brasil Sorridente (Smiling Brazil) was implemented just in 2003, inserting the dentist in the team of the Family Health Program (FHP) and creating Dental Specialty Centers for the treatment of special cases, including special needs patients. These facilities should treat cardiac patients when they require more complex procedures, after adjusting the dental field in the FHP [22].

However, the care for special needs patients in this system does not present a great resolution power. A study in a Brazilian northeastern city concluded that the care for such patients in the FHP is limited to oral health instructions and low-risk procedures. Only $20.5 \%$ of the professionals interviewed said they were trained or had subjects on special patients during their education [23]. Araújo et al. [24] found that $100 \%$ of a sample of primary care dentists did not know the risk classification of cardiac patients and the conditions in which antibiotic prophylaxis is recommended.

The lack of training of dentists limits and often prevents a regular oral health follow-up of CHD patients. Therefore, when such patients get access to dental care, the oral diseases are already established. In the daily practice of the hospital used for this study, it is common to find patients who had to travel long distances from their hometown to obtain basic dental treatment in tertiary care. They have often visited several public and private dental offices and had services denied for being cardiac patients.

This study indicated the flaws in which dental care is inserted, which corroborate the literature, showing the review points required for the dental team with a constant 
partnership with other professionals such as physicians and nurses, among others. The cross-sectional nature of the study is weak and makes it impossible to find more significant statistics on the reality studied, but it allowed the indication of demands and it can guide intervention proposals and further research projects of higher impact.

\section{CONCLUSION}

This study may conclude that the knowledge of parents on the relationship between oral infections and infective endocarditis is inconsistent and fragmented, and there is a gap between the lessons received and what is actually learned. The information are transmitted with technical terms, without explaining the action mechanism that leads to the interrelation between oral and systemic health, in an unprofessional manner and without a continued educational program.

The presence of more trained dentists is required to follow-up these children and their family members, and the pre- and postoperative care of these children cannot be curative and occur only one time. A higher participation of dentists in multidisciplinary teams would strengthen an integral care network along physicians, nurses, and other professionals of the three care levels.

\section{Collaborators}

CLS PINHEIRO, creation of the study methodology, questionnaire, single researcher, literature review, and text production. ACLO MEIRA, orientation for text production. AS Santos, creation of the study methodology, questionnaire, and orientation for data collection and final text production. DS Arcanjo, orientation for text production.

\section{REFERENCES}

1. Mitchell S, Korones S, Berenes H. Congenital heart disease in 56,109 births: incidence and natural history. Circulation. 1971;43:323-332. https://doi.org/10.1161/01.CIR.43.3.323

2. Pinto Júnior VC, Branco KM, Cavalcante $R$, Júnior Carvalho $V$, Lima JR, Freitas S. et al. Epidemiology of Congenital Heart Disease in Brazil. Braz J Cardiovasc Surg. 2015;30(2): 219-24. http://dx.doi.org/10.5935/1678-9741.20150018

3. Wilson W, Taubert K, Gewitz M, Lockhart P, Baddour $L$, Levison $M$. Prevention of Infective Endocarditis: Guideline from American Heart Association. Circulation. 2007 Oct 9;116(15):1736-54. https://doi.org/10.1161/ CIRCULATIONAHA.106.183095
4. Socransky SS, Haffajee AD, Microbiologia da doença periodontal. In: Lindhe J, Karring T, Lang NP. Tratado de periodontia clínica e implantologia oral. $4^{\text {a }}$ ed. Rio de Janeiro: Guanabara Koogan; 2005. p:105-36.

5. Wannmacher L. Profilaxia antimicrobiana em odontologia. In: Wannmacher I, Ferreira M. Farmocologia clínica para dentistas. $3^{a}$ ed. Rio de Janeiro: Guanabara Koogan; 2012. p. 351-359.

6. Damas BGB, Ramos CA, Rezende, MA. Necessidade de informação a pais de crianças portadoras de cardiopatia congênita. Rev Bras Crescimento Desenvolvimento Hum. 2009;19(1): 103-113.

7. Pimentel L, Azevedo C, Castro R, Reis R, Lorenzo A. Caries experience in young children with congenital heart disease in a developing country. Braz Oral Res. 2013; Mar-Apr;27(2):103-8. http://dx.doi.org/10.1590/S1806-83242013000100016

8. Savarna R, Rai K, Hegde A. Knowledge and oral health attitudes among parents of children with congenital heart disease. Int J Clin Ped Dent. 2011;4(1):25-28. http://dx.doi. org/10.5005/jp-journals-10005-1076

9. Haag F, Casonoto S, Varela F, Firpo C. Conhecimento dos pais sobre profilaxia de endocardite infecciosa em crianças portadoras de cardiopatia congênita. Rev Bras Cir Cardiovasc. 2011; 26 (3):413-8. http://dx.doi.org/10.5935/1678-9741. 20110016

10. Cheuk D, Wong S, Choi Y, Chau A, Cheung Y. Parent's understanding of their child's congenital heart disease. Heart. 2004;90:435-439. http://dx.doi.org/10.1136/hrt.2003.014092

11. Amaral C, Pereira L, Guy N, Amaral Filho M, Logar G, Straioto F. Oral health evaluation of cardiac patients admitted to cardiovascular pre-surgery intervention. RGO, Rev Gaúch Odontol. 2016;64(4):419-424. http://dx.doi. org/10.1590/1981-863720160003000082979

12. Coutinho AC, Maia LC, Castro G. Conhecimento dos responsáveis sobre o risco e a prevenção de endocardite infecciosa diante do tratamento odontológico. Pediatria Mod. 2007;43(1):12-21. Available from: http://www.moreirajr.com. br/revistas.asp?fase=r003\&id_materia=3518>

13. Cetta F, Bell T, Podlecki D, Ros S. Parental knowledge of bacterial endocarditis prophylaxis. Pediatr Cardilol. 1993;14:220-2. http://dx.doi.org/10.1007/BF00795374

14. Fonseca M, Evans M, Teske D, Thikkurissy S, Amini H. The impact of oral health on the quality of life of young patients with congenital cardiac disease. Cardiol Young. 2009; 19:252256. https://doi.org/10.1017/S1047951109003977

15. Almeida FA, Margoni AP, Santos MA. Compreendendo a experiência de cuidar da criança com cardiopatia congênita. Invest Qualit Saúde. 2016;2:1663-1672. http://dx.doi.org/10.15 90/S0080-623420140000800007

16. Albuquerque S, Pereira M, Fonseca A, Canavarro M. Impacto familiar e ajustamento de pais de crianças com diagnóstico de anomalia congênita: influência dos determinantes da criança. Rev Psiq Clín. 2012;39(4):136-41. http://dx.doi.org/10.1590/ S0101-60832012000400004

17. Menezes V, Cavalcanti G, Mora C, Garcia A, Leal R. Pediatric medicines and their relationship to dental caries. Braz J Pharm 
Sci. 2010;46(1):157-64. http://dx.doi.org/10.1590/S1984-82 502010000100018

18. Agrawal N, Shashikirian N, Vanka A, Thakur R, Sandhu S. Cariogenic potential of most commonly prescribed liquid oral medicines for children. PJSR 2010;3(2):7-10.

19. Rank R, Rank M, Dib J. Dificuldades maternas quanto ao uso do fio dental em crianças. UEPG Ci Biol Saúde. 2006;12(3): 31-38.

20. Teixeira C, Junior C, Silva-Sousa Y, Perez D. Tratamento odontológico em pacientes com comprometimento cardiovascular. Rev Sul-Bras Odontol. 2008;5(1):68-76.

21. Usual A, Araujo A, Diniz F, Drumon M. Necessidades sentida e observada: suas influências na satisfação de pacientes e profissionais. Arq Odontol. 2006;42(1):1-80.
22. Brasil. Ministério da Saúde, Departamento de Atenção Básica. Passo a passo das políticas de ação social em saúde. Secretaria de atenção à saúde. Brasília: Ministério da Saúde; 2016.

23. Lawrence H, Sousa L, Gonçalves F, Saintrain M, Vieira A. Acesso a saúde bucal pública pelo paciente especial: a ótica do cirurgião-dentista. Rev Bras Promoç Saúde. 2014; 27(2): 190-197.

24. Araújo A, Bavaresco C. Verificação do conhecimento da conduta de odontólogo em relação ao manejo do paciente cardiopata na atenção primária à saúde. Rev APS. 2011;14(2):197-206.

Received on: $7 / 6 / 2018$ Final version resubmitted on: 6/11/2018

Approved on: 15/2/2019 